\title{
OFFSHORE AND ONSHORE IDR MARKET: AN EVIDENCE ON INFORMATION SPILLOVER
}

\author{
Yayat Cadarajat and Alexander Lubis ${ }^{1}$
}

\begin{abstract}
This paper investigates the information transmission between off-shore and on-shore Rupiah currency markets Indonesian. We found the evidence of persistent volatility in all IDR/USD markets. Using EGARCH model on daily data for the period of 2008 - 2011, this paper provide several empirical conclusions.-First, the persistent volatility in all IDR/USD currency markets is evident. Second, the leverage effects are present in the rupiah exchange rates, indicating that IDR/USD markets have responded more to depreciation than appreciation, which is generally common in emerging market currencies. Third, the evidence of mean spillover are observed to be uni-directional; from NDF to both spot and forward rupiah markets. However, there are two ways return transmission between NDF and forward rate changes in the period of Europe crisis. Fourth, on the volatility, the spillover is only significant from NDF market to spot market for the entire period. However, in the time of crises, there is interdependence between volatility in offshore NDF and onshore spot rate changes, while information transmission is only valid from NDF to forward rate changes, not the other way around. Fifth, the negative spread of domestic interest rate may lead to depreciation pressure on the currency and positive spread may indicate the appreciation pressure.
\end{abstract}

Keywords: Foreign Exchange, Non-Deliverable Forward, exchange rate, spillover, EGARCH.

JEL Classification: F31, G13, C51

1 Yayat Cadarajat (yayat@bi.go.id) and Alexander Lubis (alexander@bi.go.id) are economist in Monetary Policy Group, Departmen of Economic Research and Monetary Policy, Bank Indonesia. The views expressed in this paper are of the authors and do not necessarily reflect those of Bank Indonesia. 


\section{INTRODUCTION}

Since Asian currency crisis in 1998, Indonesian foreign exchange market has evolved substantially. A major shift from fixed exchange rate regime to managed floating, and then to floating exchanged (IMF EREAR, 2010), has been implemented by the government. Furthermore, the currency market continues to put pressures on Indonesian Rupiah exchange rate. Nonresidents are able to access the Indonesian Rupiah deliverable forward, mostly in Singapore, either to hedge their investment or to speculate in the currency.

Therefore Bank Indonesia issued a policy that curtails the opportunity for non-residents to bet on the rupiah. Rupiah transactions were limited between onshore banks and nonresidents ${ }^{2}$. It minimizes the speculation on the Rupiah through the restriction for domestic bank to make loan in Rupiah and other linked-derivative products to the non-residents. Hence, it was a starting point where Indonesian Rupiah Non Deliverable Forward (NDF) gains its momentum.

NDF itself is a foreign exchange derivative instrument traded over-the-counter. A forward foreign exchange contract is an obligation to purchase or sell a spesific currency on a future date for a fixed price set on the date of the contract. The parties of NDF transaction settle, not by delivering the underlying pair of currencies, but making a net payment in a major currencies (generally the US Dollar) equal to the discrepancy between the agreed forward exchange rate and the succeeding realized spot fixing. NDF generally traded over the counter in an international financial center, such as New York, London, Hong Kong or Singapore.Similar with Indonesia, NDF market of other Asia has improved after the Asian currency crisis. Indonesian Rupiah is one of the biggest NDF market in Asia with average daily trading volume estimated US $\$ 10$ billion along with Philippines Peso and Chinese Renminbi (Table 1). Consequently, the implied volatility is among the highest.

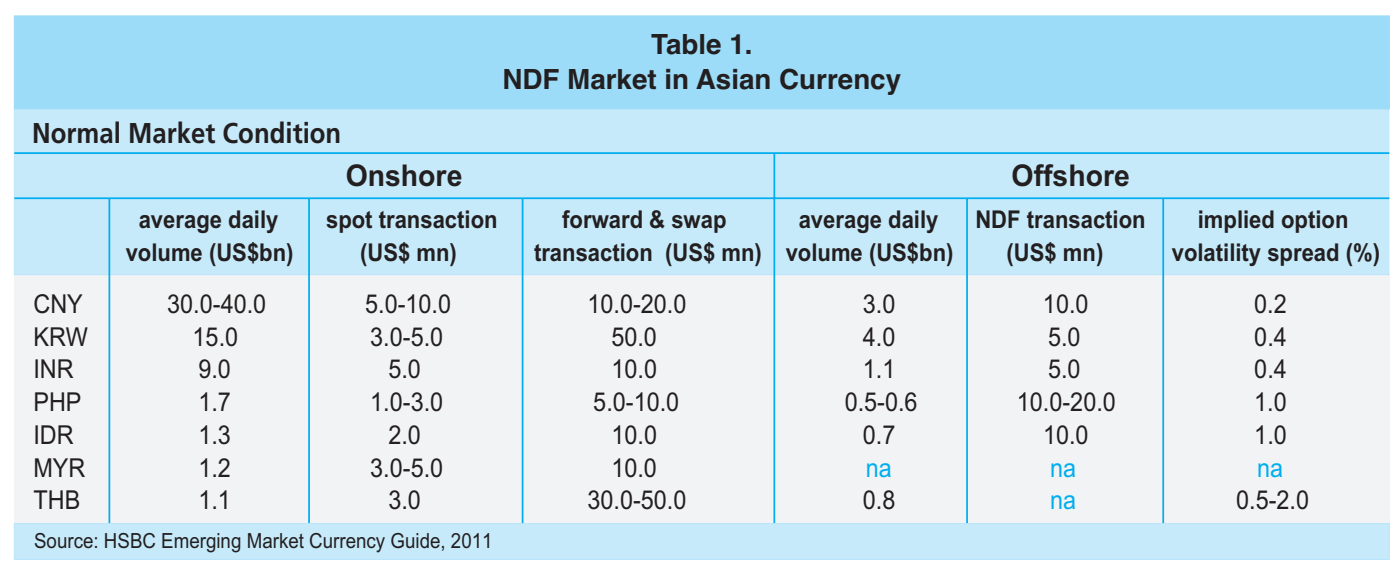

2 Bank Indonesia Regulation no 3/3/2001 dated 12 January 2001 
It is interesting to observe whether a product that trades in two different assets may reflect the same information. The difference in prices may immediately being used to arbitrage. However, Park (2001) argues that in a case of Spot and NDF may be different since the NDF grew in a result of several market problems and investment constraints that were imposed by the authority. The development of NDF itself comes from the needs of off-shore investors to hedge or to trade a currency which is strongly regulated and controlled. Therefore, it is valuable to have knowledge about the relationship and information flows between off-shore NDF and on-shore market.

The knowledge of the information may be valuable for both authority and investors. For authority, it is a very difficult task to achieve their objective if the relationship between spot and NDF is very strong. The difficulty is not only maintaining the currency stability since the NDF is being trade in off-shore market, but also conducting independent policies. For investors, the understanding of cross-market relationship may reflect about their investment strategy.

In case of Indonesian currency market, many studies have also been conducted. However, most of the papers focused on on-shore market. To the best of our knowledge, studies that investigate Indonesian Rupiah NDF market are rather limited. Perhaps, the difficulties of obtaining the data may be one of the reasons, since NDF is traded over-the-counter in offshore market. On the other hand, the movement of NDF market has attracted many attentions especially the authority. Specifically, the pressure for Indonesian Rupiah has particularlybeen increased during the current global crisis condition. Therefore, this paper attempts to provide a discussion about Indonesian Rupiah NDF Market.

Against this background, this paper aims to examine the information transmission between off-shore and on-shore rupiah currency markets. The following section briefstheory and literature on the analysis of NDF markets. Section three discusses the methodology applied in this paper to study the relationship between off-shore and on-shore for Indonesian Rupiah. The empirical results are presented in section four. The final section delivers concluding remarks of the present analysis.

\section{THEORY}

According to Lipscomb (2005), major NDF market trading began in the early 1990, originally as a product for entities to hedge their position to currency change of emerging countries with current or potential foreign exchange convertibility restrictions. NDF markets, which developed in financial centers, are beyond the authorities' jurisdiction with foreign exchange convertibility restriction. Over the time, NDF Market has been expanded in the currency that investors become more active in portfolio and/or direct investment or where a material alteration in exchange rate regime has been expected. In contrast, NDF market of the currencies 


\begin{tabular}{|c|c|}
\hline \multicolumn{2}{|r|}{$\begin{array}{c}\text { Table } 2 . \\
\text { Non-Resident Accessibility to Domestic Market }\end{array}$} \\
\hline Currency & Accessibility \\
\hline Chinese Renmibi & Foreign entities are not permitted to trade in local markets \\
\hline Indian Rupee & Permitted with underlying transactions \\
\hline Korean Won & Permitted with underlying transactions \\
\hline Indonesian Rupiah & Permitted with underlying transactions \\
\hline Philippines Peso & Permitted with underlying transactions \\
\hline Taiwan Dollar & Foreign entities are not permitted to trade in local markets \\
\hline
\end{tabular}

with more flexible in foreign exchange convertibility have been decreasing substantiality or even dissapearing.

As investment grew in emerging market, the NDF market increased in Asian currencies, especially after 1997 Asian crisis. The NDF provides an a subtitute hedging instrument for foreign investors with local currency exposure or speculative instrument for them to take position in the local currency. The Asian NDF market reflects restrictions on their access on local market (Tabel 2).

It may be an interesting fact that the Malaysian Ringgit and Thai Bath are not included in major Asian NDF market, nevertheless they restrict on foreign exchange convertibility. Misra and Behera (2006) argues that there are certain policies that were imposed to restrict the development of NDF in both currencies. In the case of Malaysia, a switching in exchange rate regime to fixed exchange rate has been preventing a further development of Malaysian Ringgit NDF market. Furthermore, the absence of exchange rate reference made the settlement of Malaysian Ringgit NDF became more difficult. Domestic banks in Malaysia are also not allowed to have forward transaction with foreign counterparties which restricting the foreign counterparties capabilities to hedge their NDF positions. In Thailand, the central bank of Thailand discourages foreign banks to qoute in Thai Bath NDF market through their domestic branches.

The pricing of most forward foreign exchange contract is mainly derived from the interest rate parity formula that measures equivalent returns over a set time period based on two currencies' interest rate and the current spot exchange rate. Similar with other financial products, there are other factors that may contribute to the NDF prices such as trading flows, liquidity ${ }^{3}$, and counterparty risk. The expectation of changes in exchange rate regime, speculative positioning, conditions on local interest rate market and the correlation between on-shore and off-shore forward markets are also attributed to the NDF prices. When off-shore investors

3 It can be argued that different price quotations in different financial centers are caused by the availability of the NDF seller, for example Indonesian Rupiah quotation in New York Market and Singapore Market may have different quotation due to the liquidity problem. 
have a small access to on-shore interest markets, the NDF prices are mainly derived from the expectation of future level of spot exchange rate (Lipscomb, 2005).

According to the efficient market hypothesis, asset prices fully reflect all of the available information. Arbitrage involves similar price financial instruments between two or more markets will generate losses. Hence, a movement in one market'sprice should be responded by other markets' price that sell the same instrument. If the other markets does not respond that particular movement, one institution may take that the advantage to arbitrage between these markets.

The relationship of both on-shore and off-shore markets without the presence of capital control can be draw from covered interest parity:

$$
F=S(1+r) /\left(1+r^{\$}\right)
$$

where, $F$ is the forward rate, $S$ is the spot rate, $r$ is the interest rate on home currency and $r^{\$}$ is the US Dollar Interest rate. The equation holds when there is no barrier for cross border transaction that includes borrowing and lending.

However, when a capital control applies then non-residents may be restricted to have full access to onshore market. Therefore, NDF applies as a substitute of the forward rate.

$$
N D F=S(1+r) /\left(1+r^{\$}\right)
$$

Moreover, the sign of the onshore-offshore yield spread can indicate the underlying market pressure on the currency. If the domestic interest rate is higher than the NDF implied yield may imply the appreciation pressure on domestic currency. However, such capital control may restrict the capital inflow to move freely. Lower domestic interest rate than the NDF implied yield may suggest the depreciation pressure on domestic currency, whilea zero spread may represent the absence of market pressure on both domestic and offshore market.

The literature on the study of interrelation between NDF rate and onshore spot and forward rates are rather limited. Park (2001) is one of the earliest which examine the information flows between the Korean Won-dollar spot and offshore NDF markets. He focused on the impact of the reform in Korean exchange rate system especially concerning the relationship between offshore and onshore markets. Applying the augmented GARCH procedures, he found that during the pre-reform period there is a mean spillover from the spot to the NDF market, but not on the other way round and that the evidence of volatility spillover is exist in both directions. The reform has changed the situation that the flows arereversed; both the mean and volatility spillover are present from the NDF to the spot markets. On the contrary, in his attempts to examine the hypothesis of market efficiency in Renminbi currency trading, 
Izawa (2006) found that the hypothesis is rejected and Renminbi NDF is not an unbiased predictor of the future spot rate.

Ma et al. (2004) found that Asian NDFs are generally not strongly connected to their spot counterparts due to the more directed spot exchange rates. In addition, they also exhibit that Asian NDFs have positive cross correlation more to each other than to the spot markets for the period of March 2001 to February 2004. The currency management by the authorities in Asia tends to constrain the response of the spot exchange rate to changes in global market volatility, hence the NDF rate move with higher volatilities than the spot markets normally do (Cairns et al 2007).

Moreover, Colavecchio and Funke (2006) use multivariate GARCH method to study the volatility overflow between Chinese NDF market and seven of its Asia Pacific counterparts over the period of January 1998 to March 2005. They found that Renminbi NDF has determined several of Asian currency markets in various levels. Studying the volatility transmission between Indian rupee (INR) NDF market and its onshore spot and forward markets, Mehra and Behera (2006) found that NDF market is generally affected by spot and forward markets, and the volatility spillover effect are exist from onshore market to NDF market. However, they also recognize the reversed direction in volatility overflows; from NDF to spot market, though it is rather weaker.

Regarding the use of ARCH-GARCH model in studying the information transmission mechanism in currency markets, we follow Park(2001) and Misra and Behera(2006). However, the utilization of EGARCH model is chosen to capture the asymmetric and volatility clustering simultaneously. The essence of asymmetric issues has been discussed by Bekaert and Wu (2000) and Michayluk et al (2006). Moreover, Eagle and $\mathrm{Ng}$ (1993) and Stevenson (2003) have provided evidence that EGARCH model performed remarkably well. We also found that $\mathrm{Ng}$ (2000) and Christiansen (2003) used multistep EGARCH to analyze the volatility and mean spillover process in the financial market data.

Overall, the previous analyses note that there is inter-relationship between various crosscurrency NDFs and between onshore markets and NDF market. Therefore, study on the behavior of IDR NDF market and its relationship with the onshore spot and forward markets would be beneficial for market players as well as the authority.

\section{METHODOLOGY}

Augmented Dickey -Fuller (ADF) tests were applied to check the stationarity of all series. In addition, Johansen cointegration test is performed to investigate the long-run relationship between offshore NDF rate and onshore of spot and forward rates. Due to the sensitivity of the estimation results to the lag length selection, the most widely used procedure is to determine a Vector Autoregression (VAR) model on the non-differenced data in order to determine the 
lag length for Johansen test (Enders, 2004). In choosing between the various lag length selection criteria, we follow Johansen et al (2000) to prefer Hannan-Quinn Criteria (HQC). Again, we employ the LM test to check for serial correlation in the error terms. Moreover, the Granger causality test is used to investigate the causal relationship between offshore NDF and onshore currency rate changes.

To examine the offshore and onshore information transmission of Indonesian rupiah, we then continued with our volatility analysis and applied a bivariate extension of the $\operatorname{EGARCH}(p, q)$ model of Nelson (1991) in order to examine whether the volatility of NDF returns affects and is affected by the volatility of domestic spot and forward. EGARCH has three fundamental advantages compared to the standard GARCH model of Bollerslev (1986): i) the standard GARCH model cannot capture the asymmetric behavior of the conditional variance in the assets price returns. ii) Contrary to the standard GARCH model where to ensure positive conditional variances all the times, the parameters of the GARCH models must be non-negative, there is no parameter restrictions required in the EGARCH model sinceit is in exponential form. iii) Persistence of conditional variance can be captured in the EGARCH model by the coefficient of its lag.

The estimation of this study is performed within structure of atwo-step model as we found in Hamao et al (1990), Park (2001), Ng (2000) and Christiansen (2003). The standard $\operatorname{EGARCH}(p, q)$ model applied in our study is described by the conditional mean and the conditional variance equations (3) and (4) shown below.

$$
\begin{aligned}
R_{i, t}=\alpha_{i} & +\Phi_{i} \varepsilon_{i, t-1}+\varepsilon_{i, t} \\
\ln \left(\sigma_{i, t}^{2}\right)= & \omega_{i}+\sum_{k=1}^{p} \beta_{i, k}\left|\frac{\varepsilon_{i, t-1}}{\sqrt{\sigma_{i, t-1}}}-\sqrt{2 / \pi}\right|+\sum_{k=1}^{p} \delta_{i, k} \frac{\varepsilon_{i, t-1}}{\sqrt{\sigma_{i, t-1}}} \\
& +\sum_{k=1}^{p} \theta_{i, k} \ln \left(\sigma_{i, t-1}^{2}\right)
\end{aligned}
$$

where $R_{i, t}$ denote returns on IDR/USD currency market includes offshore NDF, onshore spot and forward. We add $\varepsilon_{i, t-1}$ or $\mathrm{MA}(1)$ to the mean equation to detect serial correlation in the exchange rate changes. It is the IDR/USD that we used to investigate the relationship among currency market returns. The stochastic error terms $\left(\varepsilon_{i, t}\right)$ are acquired in order to be used in the EGARCH models.

Equation (2) specifies conditional variance where $\omega_{i}$ is constant or mean of variance equation, $\frac{\varepsilon_{i, t-1}}{\sqrt{\sigma_{i, t-1}}}$ is the standardized residuals of the exchange rate returns, the ARCH term, which provide the impact of information of previous periods on the return volatility. The EGARCH 
model allows for leverage effects (asymmetric). The coefficient $\delta_{i, k}$ in equation (2) examines asymmetry effect in those currency markets. If the $\frac{\varepsilon_{i, t-1}}{\sqrt{\sigma_{i, t-1}}}$ is positive, then the effect of the innovation on the conditional variance is $\delta_{i, k}+\beta_{i, k}$. If the $\frac{\varepsilon_{i, t-1}}{\sqrt{\sigma_{i, t-1}}}$ is negative, the effect of the shock on the volatility is $-\delta_{i, k}+\beta_{i, k}$. Furthermore, the coefficient $\beta_{i, k}$ investigates volatility clustering in all series.

It is common that currency markets are known to have volatility autocorrelation. A statistically significant $\beta_{i, k}$ can give confirmation that volatility in IDR/USD markets are affected by their historical volatility changes. Volatility autocorrelations are fairly often identified in currency markets. Moreover, $\sigma_{i, t}^{2}$ denote conditional variance of exchange rate returns. The lagged conditional variance $\left(\sigma_{i, t-1}^{2}\right)$ denote previously forecast variance, the GARCH term, that may have impact on the volatility. An information shock in the market tends to have continuous effect in the upcoming volatility. Statistically significant coefficient of the GARCH terms can be understood as the presence of the persistent volatility.

Concerning the appropriate lag length selection, three information criterions are commonly used for indicating the proper model, including Akaike Information criteria (AIC), Schwartz (Bayesian) Information Criterion (SIC) and Hannan-Quinn Criterion (HQC). The lags were chosen based on the HQC. Shittu and Asemota (2009) found that HQC performs best for selecting the correct order of an autoregressive model for large samples, while SIC is most suitable for smaller samples.

The residuals tests were conducted to examine the efficiency of the fitted model. LM test is used to identify possible presence of remaining ARCH effects. The detection of conditional heteroscedasticity is employed through the regression of squared residuals on constant and lagged squared residuals up to lag $q$. The LM test was carried out under the null hypothesis of no additional $A R C H$ effect. In addition, the test for existence of serial correlation between NDF and Spot and forward rate changes were conducted. Ljung-Box (L-B) Q(12) and L-BQ2 (12) are estimated to survey for linear and non-linear dependence (autocorrelation) of all series.

In the ARCH and GARCH family of models, exogenous variables can be included in the mean equation as well as in the conditional variance equation. The extended model is shown in equations (5) and (6) below:

$$
\begin{aligned}
R_{i, t}=\alpha_{i} & +\Phi_{i} \varepsilon_{i, t-1}+\partial_{i} R_{j, t-1}+\varepsilon_{i, t} \\
\ln \left(\sigma_{i, t}^{2}\right)= & \omega_{i}+\sum_{k=1}^{p} \beta_{i, k}\left|\frac{\varepsilon_{i, t-1}}{\sqrt{\sigma_{i, t-1}}}-\sqrt{2 / \pi}\right|+\sum_{k=1}^{p} \delta_{i, k} \frac{\varepsilon_{i, t-1}}{\sqrt{\sigma_{i, t-1}}} \\
& +\sum_{k=1}^{p} \theta_{i, k} \ln \left(\sigma_{i, t-1}^{2}\right)+\gamma_{i} \varepsilon_{j, t-1}^{2}
\end{aligned}
$$


In the equations (5) and (6), we augmented the best fitted $\operatorname{EGARCH}(p, q)$ model estimatedby equation (3) and (4). If $R_{i, t}$ is NDF return, then we included $R_{j, t-1}$ as a return of onshore IDR/USD spot or forward to the mean equation. The statistically significant of coefficient ${ }_{i}$ will suggests that there is a mean spillover between offshore and onshore exchange rate changes. Furthermore, our extension to the conditional variance equation is implemented by adding $\varepsilon_{j, t-1,}^{2}$ the previous period of squared standardized innovation applied to $R_{j, t}$. The coefficient $\gamma_{i}$ tests whether thevolatility spillovers exist across the offshore NDF and domestic IDR currency markets.

\section{RESULT AND ANALYSIS}

\subsection{Preliminary Analysis}

Indonesian Rupiah (IDR) NDF is traded largely in Singapore and small exposures in Hong Kong and New York. The need of hedging instrument of IDR as previously mention, is one of the reason IDR NDF being traded. The thin on-shore forward market drives most of foreign investors to seek hedging instrument in offshore. The other reason is to provide an instrument for foreign investor to speculate on IDR exchange. Foreign investors are not allowed to access on-shore market without any underlying economic activities ${ }^{4}$.

Almost all of IDR NDF market player are foreign investors. This is because domestic banks were prohibited to conduct margin trading against IDR ${ }^{5}$. However, domestic banks may be allowed to involve in margin trading on a pair of other currencies which subject to certain condition.

In market, there is bid ask spread that reflects the transaction cost including risk perception in the market. In an efficient market, price contains all of the information in the market. A deeper market may reduce the bid ask spread. From the daily data that taken from January 3 , 2011 to October 21, 2011, Indonesian Rupiah has the highest bid ask spread in both spot

\begin{tabular}{|c|c|c|c|c|c|c|}
\hline \multicolumn{7}{|c|}{$\begin{array}{l}\text { Table } 3 . \\
\text { Bid Ask Spread Asian Currency in } 2011 \text { (up to } 19 \text { October 2011) }\end{array}$} \\
\hline & \multicolumn{2}{|c|}{ SPOT } & \multicolumn{2}{|c|}{ FORWARD 1M } & \multicolumn{2}{|c|}{ NDF $1 \mathrm{M}$} \\
\hline & $\begin{array}{l}\text { Onshore } \\
\text { bid/ask spread }\end{array}$ & $\begin{array}{l}\text { Volatility } \\
\text { 10D }\end{array}$ & $\begin{array}{l}\text { Onshore } \\
\text { bid/ask spread }\end{array}$ & $\begin{array}{l}\text { Volatility } \\
\text { 10D }\end{array}$ & $\begin{array}{l}\text { Offshore } \\
\text { bid/ask spread }\end{array}$ & $\begin{array}{l}\text { Volatility } \\
\text { 10D }\end{array}$ \\
\hline IDR & 8,01 & 0,36 & 0,09 & 1,47 & 19,51 & 2,29 \\
\hline KRW & 1,56 & 0,90 & 493,92 & 5,83 & 0,06 & 0,50 \\
\hline PHP & 0,05 & 0,90 & 0,05 & 0,90 & 1,19 & 0,77 \\
\hline MYR & 0,00 & 1,06 & 0,08 & 1,02 & 0,00 & 0,59 \\
\hline CNY & 0,00 & 0,64 & 0,43 & 10,65 & 0,00 & 0,15 \\
\hline
\end{tabular}

4 Bank Indonesia Regulation No. 10/28/PBI/2008

5 Bank Indonesia Regulation No. 7/31/PBI/2005 
onshore and NDF offshore markets (Table 3). It may reflect that lowering liquidity in those markets comparing to other Asian countries.

On the other hand, volatility in spot Rupiah market is the lowest among other Asian countries whereas the NDF volatility is the highest. It is attributed to the intervention in the spot market by Bank Indonesia has successfully reduced the on-shore market volatility.

If we look closer to IDR market, the liquidity has been improved after the subprime crisis which culminated in Lehman Brothers bankruptcy (Table 4). The data also indicates that onshore liquidity is better than the offshore market. It can be observed from the bid-ask spread of onshore market is lower than the offshore.

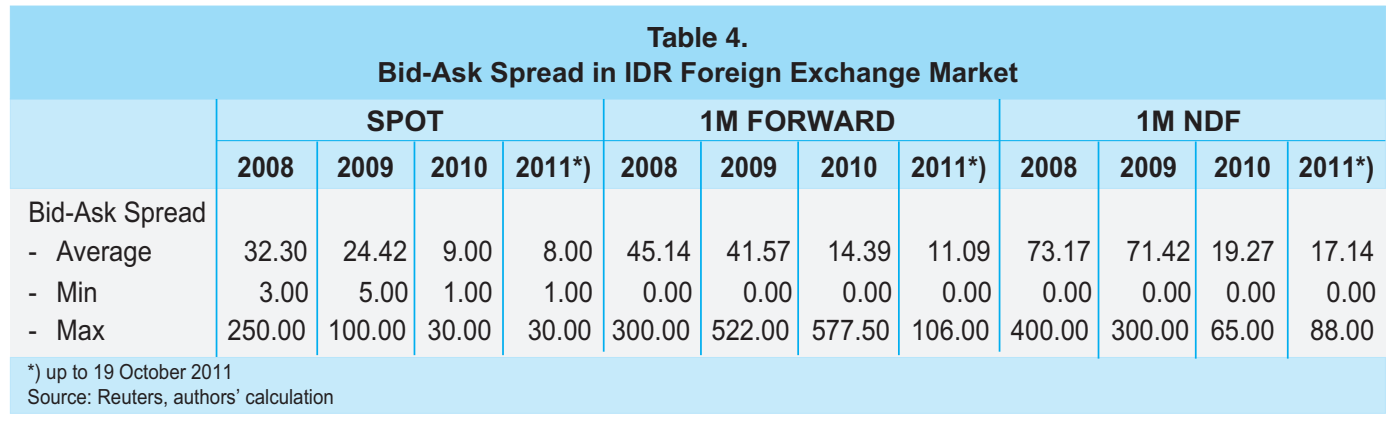

In 2008 and 2009, Indonesian onshore market has been suffered from the global turmoil. The minimum and maximum bid-ask spread in the onshore spot market on these years varied largely from IDR 3 to IDR 250 in 2008 and from IDR 5 to IDR 100 in 2009. The similar thing also happened in both onshore forward market and NDF market. It may reflect a period where liquidity in onshore market was under pressure from the demand of capital outflows. However, in 2010 and 2011, where the European debt crisis fueled the capital inflows to emerging market, the liquidity in both onshore and offshore market is increasingly better. The bid-ask spread in average for spot market has been decreased dramatically to IDR 9 in 2010 and IDR 8 in 2011. The bid-ask spread for NDF market has also been lowered. The deviation between minimum and maximum bid-ask spread also diminished. However, in the case of onshore forward market, the bid-ask spread may be still high during the day before the long holiday

\begin{tabular}{|l|c|}
$\begin{array}{c}\text { Table. } \mathbf{5} \text { Volatility of IDR Market in } 2011 \\
\text { (up to 19 October 2011) }\end{array}$ \\
\hline \multicolumn{1}{|c|}{ MARKET } & VOLATILITY \\
\hline Spot & 0.36 \\
\hline Forward & 1.47 \\
\hline 1M NDF & 2.30 \\
\hline Source: Reuters, authors' calculation \\
\hline
\end{tabular}


period in Indonesia. It can be argue that due to high uncertainty in global market while Indonesian market is having a long break creates a need for the investors to hedge their positions. Therefore, it may give a liquidity pressure in the market.

\subsection{Estimation Result}

This study uses daily data spanning from 2008 to 2011. In addition to full sample, we also specifically observe the information interaction between offshore and onshore IDR market in the period of Subprime crisis as well as Europe sovereign crisis. Subprime crisis may represent a period where IDR was having a heavy depreciation pressure whereas Europe sovereign crisis may represent the appreciation pressure. Hence, different type of pressure may have different implication about the information interaction.

The ADF tests indicate that all the return series are having unit root at level but not in first differences.

\begin{tabular}{l|c|c|c}
\multicolumn{3}{c}{ Table 6. } \\
\multicolumn{3}{c}{ Augmented Dickey-Fuller Unit Root Test } \\
Full sample & Critical Value & Level & First Difference \\
\hline Spot & $-3.97(1 \%)$ & -1.75 & -28.82 \\
Forward & $-3.97(1 \%)$ & -2.27 & -27.43 \\
NDF & $-3.97(1 \%)$ & -2.25 & -29.36 \\
\hline Sub-sample I: Subprime crisis & $-3.99(1 \%)$ & -1.67 & -15.58 \\
\hline Spot & $-3.99(1 \%)$ & -2.42 & -15.44 \\
Forward & $-3.99(1 \%)$ & -2.18 & -15.44 \\
NDF & $-3.44(1 \%)$ & -1.11 & -23.88 \\
\hline Sub-sample II: Europe sovereign crisis & -1.85 & -11.42 \\
\hline Spot & $-3.44(1 \%)$ & -2.73 & \\
Forward & $-3.44(1 \%)$ &
\end{tabular}

Table 7 shows the descriptive statistic for NDF, spot and forward rate changes. Negative mean are found in full sample and sub-sample II (European sovereign debt crisis), while subsample I (Subprime crisis) has positive mean. In the recent period of sub-sample II, NDF rate changes has the highest standard deviation about $0.5 \%$ in comparison to $0.3 \%$ and $0.4 \%$ for spot and forward rate changes respectively. This preliminary analysis also indicates that all the return series are leptokurtic. Furthermore, Jarque-Bera (JB) test implies that all series of exchange rate changes are non-Gaussian, having non-normal distributions. Finally, Ljung-Box tests to the 
returns and its squared series shows that the volatility of these series is time varying and is clustering. This implied by both $\mathrm{Q}(12)$ and $\mathrm{Q}^{2}(12)$ that are statistically significant at $1 \%$ level. This indicates the event of linear and non-linear dependency, and thus requires the use of $\mathrm{ARCH}$ or GARCH models to capture the presence of ARCH effects.

\begin{tabular}{|c|c|c|c|c|c|c|c|}
\hline \multicolumn{8}{|c|}{$\begin{array}{c}\text { Table } 7 . \\
\text { Descriptive Statistic for Forward, NDF and Spot Rate Changes }\end{array}$} \\
\hline & Mean $\left(\times 10^{3}\right)$ & Std. Dev. & Skewness & Kurtosis & JB & $Q(12)$ & $Q^{2}(12)$ \\
\hline \multicolumn{8}{|c|}{ Full sample } \\
\hline Forward & -0.038 & 0.020 & -0.948 & 366.994 & 5277732 & 185.300 & 239.18 \\
\hline NDF & -0.038 & 0.009 & 1.839 & 21.096 & 13582.1 & 27.336 & 627.86 \\
\hline Spot & -0.042 & 0.006 & 1.609 & 58.660 & 123819.3 & 51.767 & 32.857 \\
\hline \multicolumn{8}{|c|}{ Sub-sample I: Subprime crisis } \\
\hline Forward & 0.858 & 0.035 & -0.639 & 123.363 & 175073.8 & 60.301 & 72.10 \\
\hline NDF & 0.878 & 0.014 & 1.565 & 11.957 & 1087.7 & 23.933 & 157.53 \\
\hline Spot & 0.801 & 0.008 & 1.564 & 41.237 & 17785.0 & 33.067 & 7.9681 \\
\hline \multicolumn{8}{|c|}{ Sub-sample II: Europe sovereign crisis } \\
\hline Forward & -0.071 & 0.004 & 0.422 & 12.880 & 1655.0 & 42.543 & 93.481 \\
\hline NDF & -0.063 & 0.005 & 0.965 & 14.088 & 2132.2 & 51.713 & 276.45 \\
\hline Spot & -0.075 & 0.003 & 2.142 & 28.861 & 11567.3 & 30.378 & 57.099 \\
\hline
\end{tabular}

Two non-stationary series are said to be cointegrated if the linear combination of them are stationary. This suggests that both series move together through time, and they called to have cointegrating relationship. In testing cointegration, following Johansen technique, we find that offshore NDF rate and onshore spot or forward rates are stationary even though all the returns series are individually non-stationary (Table 8). In other words, NDF rate and spot rate, as well as NDF rate and forward rate are cointegrated. This indicates the presence of such stable long-term relationships between NDF rates and spot rate, and NDF rate and forward rate in all periods of sample sets. The estimated cointegrating coefficients are close to one, pointing to the existence of long-run equilibrium relation. Accordingly, we then use exchange rate changes in the estimation of spillover effects.

To provide some insight on the information transmission mechanism, now we perform Granger causality tests to address the direction of causality between offshore and onshore currency market. This attempt is proposed to investigate particularly the lead-lag linkage between volatilities in these markets. The causality in the Granger terms involves the usage of F-test to carry out a joint test of whether lagged information of market " $i$ " provides any statistically significant information about market " $j$ " in the presence of knowledge on lagged market " $j$ ". Granger causality is a terms for specific view of causality in time series analysis, which does not indicate causality in the broader use of the terms. 


\begin{tabular}{|c|c|c|c|}
\hline \multicolumn{4}{|c|}{$\begin{array}{c}\text { Table } 8 . \\
\text { Johansen Cointegration Test }\end{array}$} \\
\hline $\begin{array}{l}\text { Hypothesized } \\
\text { No. of CE(s) }\end{array}$ & Eigenvalue & $\begin{array}{l}\text { Trace } \\
\text { Statistic }\end{array}$ & $\begin{array}{c}5 \% \text { Critical } \\
\text { Value }\end{array}$ \\
\hline \multicolumn{4}{|l|}{ Full sample } \\
\hline \multicolumn{4}{|l|}{$N D F=-1.102 * S P O T$} \\
\hline None * & 0.099 & 101.751 & 15.495 \\
\hline At most 1 & 0.002 & 2.145 & 3.841 \\
\hline \multicolumn{4}{|l|}{$N D F=-1.045^{\star} F W D$} \\
\hline None * & 0.288 & 326.744 & 15.495 \\
\hline At most 1 & 0.003 & 3.114 & 3.841 \\
\hline \multicolumn{4}{|c|}{ Sub-sample I: Subprime crisis } \\
\hline \multicolumn{4}{|l|}{$N D F=-1.121^{*} S P O T$} \\
\hline None * & 0.113 & 35.007 & 15.495 \\
\hline At most 1 & 0.002 & 0.606 & 3.841 \\
\hline \multicolumn{4}{|l|}{$N D F=-1.052^{*} F W D$} \\
\hline None * & 0.344 & 121.940 & 15.495 \\
\hline At most 1 & 0.005 & 1.344 & 3.841 \\
\hline \multicolumn{4}{|c|}{ Sub-sample II: Europe sovereign crisis } \\
\hline \multicolumn{4}{|l|}{$N D F=-0.995^{\star} S P O T$} \\
\hline None * & 0.050 & 22.189 & 15.495 \\
\hline At most 1 & 0.004 & 1.769 & 3.841 \\
\hline \multicolumn{4}{|l|}{$N D F=-0.996^{\star} F W D$} \\
\hline None * & 0.036 & 16.662 & 15.495 \\
\hline At most 1 & 0.005 & 2.114 & 3.841 \\
\hline
\end{tabular}

Table 9 reports the result of Granger causality test. We found a bi-directional causality between NDF and spot rate changes in all sample periods, even though the effect of onshore spot rate changes to that of the offshore NDF rate has lower significance than its reverse causality. Moreover, parallel result is also evident between NDF and forward returns in subsample II of Europe sovereign crisis. This is different from the results in full sample and subsample I (Subprime crisis) that suggests only one-directional causality from NDF rate changes to forward rate changes. This implies that shock originated in a market (e.g. offshore NDF) has significant effects on the volatility of other market (e.g. onshore spot or forward).

The preliminary analysis indicates the incidence of strong autocorrelation and significant conditional heteroskedasticity, as often occurs to the majority of daily data. Thus, it is necessary to use the MA(1)-EGARCH $(p, q)$ to capture these ARCH effects.

We Initially estimated univariate $\operatorname{EGARCH}(p, q)$ basen on equation (3) and (4). We estimate full sample period consisting 956 observations spanning from February 20, 2008 to October 19, 2011. Additional to full sample estimation, we estimate first sub-sample consisting of 290 


\begin{tabular}{|c|c|c|}
\hline \multicolumn{3}{|c|}{$\begin{array}{c}\text { Table } 9 . \\
\text { Granger Casuality Test }\end{array}$} \\
\hline Null Hypothesis: & F-Statistic & p-values \\
\hline \multicolumn{3}{|l|}{ Full sample } \\
\hline DLNDF does not Granger Cause DLFWD & 65.054 & 3.E-38 \\
\hline DLFWD does not Granger Cause DLNDF & 1.416 & 0.2366 \\
\hline DLSPOT does not Granger Cause DLNDF & 6.508 & 0.0002 \\
\hline DLNDF does not Granger Cause DLSPOT & 25.209 & $1.0 \mathrm{E}-15$ \\
\hline \multicolumn{3}{|l|}{ Sub-sample I: Subprime crisis } \\
\hline DLNDF does not Granger Cause DLFWD & 25.274 & $8.0 \mathrm{E}-11$ \\
\hline DLFWD does not Granger Cause DLNDF & 0.598 & 0.5508 \\
\hline DLSPOT does not Granger Cause DLNDF & 4.795 & 0.0294 \\
\hline DLNDF does not Granger Cause DLSPOT & 22.815 & $3.0 \mathrm{E}-06$ \\
\hline \multicolumn{3}{|l|}{ Sub-sample II: Europe sovereign crisis } \\
\hline DLNDF does not Granger Cause DLFWD & 7.658 & $6.0 \mathrm{E}-06$ \\
\hline DLFWD does not Granger Cause DLNDF & 4.896 & 0.0007 \\
\hline DLSPOT does not Granger Cause DLNDF & 4.477 & 0.0006 \\
\hline DLNDF does not Granger Cause DLSPOT & 11.743 & 1.0E-10 \\
\hline
\end{tabular}

observations for the period of February 20, 2008 to March 31, 2009 regarding Subprime crisis, whereas the second sub-sample consists of 405 observations for the period of April 1, 2010 to October 19, 2011 concerning European crisis.

Table 10 shows the best fitted model for our data in the full sample. We select different order of ARCH and GARCH for different series and sample period according to HQ Criteria. The best fitting model for spot rate changes in the full sample are $\operatorname{EGARCH}(1,2)$, whereas $\operatorname{EGARCH}(1,4)$ and $\mathrm{EGARCH}(1,1)$ are those for forwardrate and NDF rate changes respectively. Moreover, we choose $\operatorname{EGARCH}(2,3)$ as the most fittedfor thesub-sample I regarding spot and NDF returns, while EGARCH(1,3) is selected for forward return. Furthermore, regarding subsample II, we found that $\operatorname{EGARCH}(1,2), \operatorname{EGARCH}(2,3)$ and $\operatorname{EGARCH}(1,1)$ are respectively elected models for spot, forward and NDF returns.

The Ljung-Box Q(12) and $Q^{2}(12)$ statistic for the normalized EGARCH residuals and their squared are statistically insignificant, indicating that the estimated models have appropriate specifications. Besides, LM (12) tests are also failed to reject the null hypothesis of no additional remaining $\mathrm{ARCH}$ effects.

Succeeding these mostly positive results, we introduced the return in counterpart market $\left(R_{j, t-1}\right)$ in the preceding trading day into the mean equationas an explanatory variable. Similarly, 


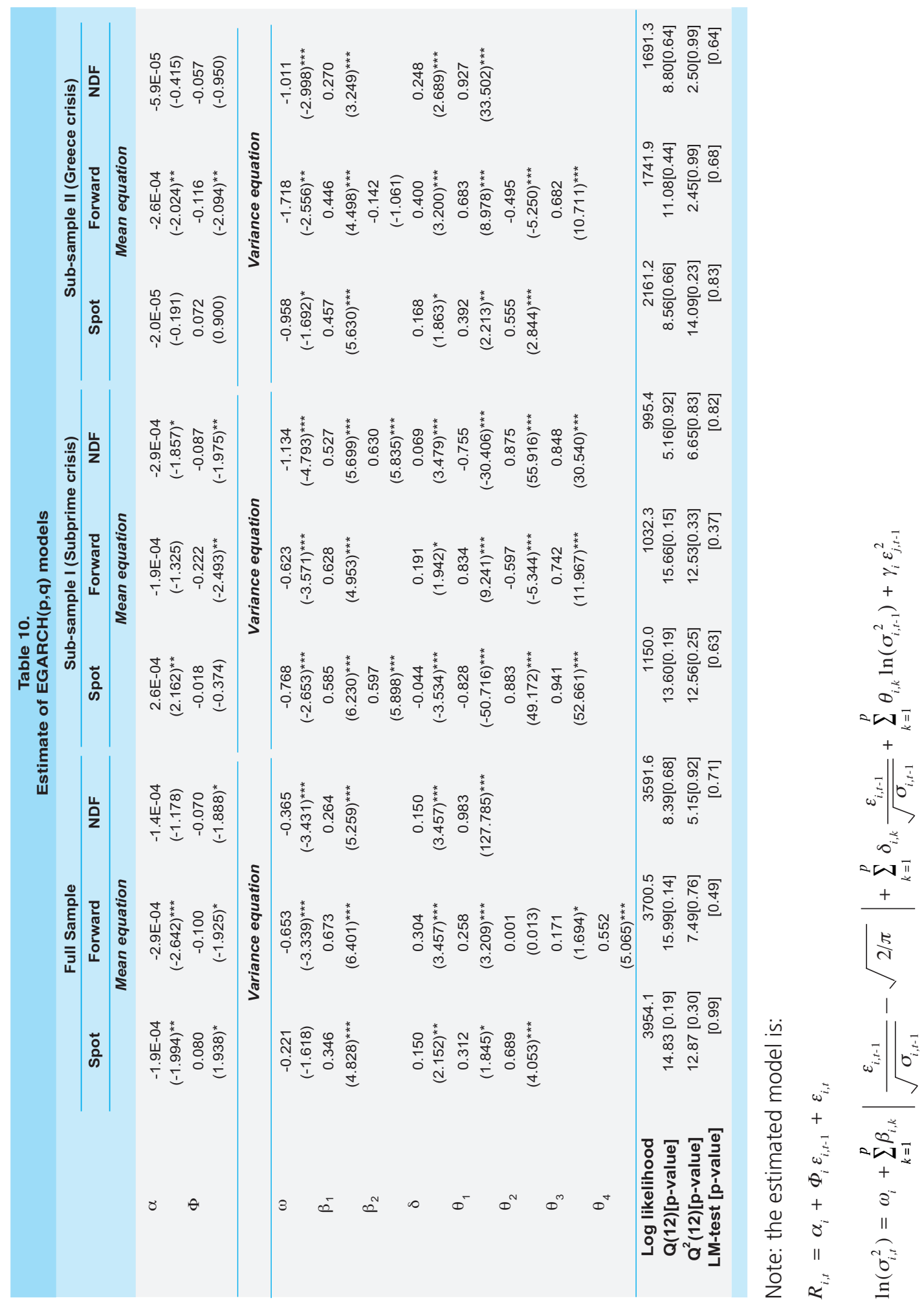


we included squared standardized residual from the estimated $\operatorname{EGARCH}(p, q)$ into the conditional variance equations as an exogenous variable as seen in equation (3) and (4). Table 8-10 exhibits the estimation results for full sample, sub-sample I (Subprime crisis) and sub-sample II (European crisis) respectively.

The coefficients on volatility persistence $\theta_{i, k}$ are all statistically significant for spot, NDF and forward returns for all sample sets. Wu (2005) notes that in order the volatility process to be stable, it is necessary that $\sum_{k=1}^{p} \theta_{i, k}$ are all less than one. The results indicate that the volatility persistence is stable. It applies for all spot, NDF and forward returns for all sample periods.

In terms of return spillover, the evidence in the full sample estimation exhibits unidirectional return spillover from NDF to both spot and forward rupiah markets. Similar results are also found in sub-sample I. However, the coefficients of mean spillover between NDF and spot returns are statistically insignificant for sub-sample II. On the contrary, the results confirm the existence oftwo ways return transmission between NDF and forward rate changes.

Regarding the volatility spillover effects from offshore to onshore markets, we found that there are some considerable different between the results for the entire period and the periods of both Subprime and Europe crises. For the crises periods, the volatility transmissions are significant from NDF to both spot and forward rate changes. Significant coefficient indicates that volatility information contained in NDF market has affected the volatility in the spot as well as forward markets. However, for the entire period, the volatility spillover is only found from NDF to spot rate changes.

In terms of volatility spillover from both onshore spot and forward markets to the offshore NDF market, we found that for the entire period, the estimated coefficients are statistically insignificant. The evidences of volatility spillover are found in both crises periods, especially from spot market to NDF market. This perhaps related to the characteristic of the onshore IDR/ USD markets, i.e. thin market with limited liquidity. The volatility in the IDR currency market during those crises weregenerally higher than normal period, and went along with currencies of regional and emerging markets, which is mainly attributed to the flight to quality and the deleveraging process by global investors. In the meantime, given the limited liquidity in the onshore spot market, capital reversal from the rupiah assets resulted in an excess demand for USD and a spike in spot market volatility. Global investors, then often enter IDR NDF market to meet their demand for USD which in turn leads to the rise of volatility in the market.

A positive sign on the spillover coefficient suggests that an increase in volatility in one market is related with increased volatility in the other market, while a negative coefficient implies that increase volatility in one market associated with decreased volatility in the other market. We found a different significant coefficient for the spillover effect from NDF market to forward market. The coefficient is negative and significant in the Subprime crisis period, while 
it is positive and significant for the period of Europe crisis. This may indicate that the volatility spillover from NDF to forward markets is not constant over time (Morales, et al 2006).

We found some evidences where there is a different significance between mean and volatility spillover i.e. mean spillover is statistically significant while volatility spillover is insignificant. Lee (2010) suggests that the first-moment (return) and second-moment (volatility) contain different set of information, which have important implications for investor on his practical investment decision, and also important for the authority.

Regarding the asymmetric volatility effect (leverage effect), the estimated coefficients arestatistically significant for all IDR currency markets with the exception for the forward market in the period of Subprime crisis. Positive sign on coefficient of asymmetric volatility may indicate that the volatility in IDR markets have responded more to depreciation than appreciation. On the contrary, negative value may suggest that volatility in the IDR markets has responded more to appreciation than depreciation. We found the evidence of negative and significant coefficient of asymmetric volatility in the spot market for the period of Subprime crisis. However, the most common evidence for IDR market is that it has responded more to depreciation than appreciation, which is consistent with the study of Cairns et al(2007) who found that emerging market currencies generally depreciate in an environment of elevated volatility. Furthermore, the lack of significance of asymmetric volatility coefficient as found in forward market for the Subprime crisis period implies for that volatility of forward market has responded symmetrically to both appreciation and depreciation. 


\begin{tabular}{|c|c|c|c|c|}
\hline & \multicolumn{3}{|c|}{$\begin{array}{l}\text { Table } 11 . \\
\text { Mean and Volatility Spillover: Total Sample }\end{array}$} & \\
\hline & \multicolumn{4}{|c|}{ Full Sample } \\
\hline & NDF - Spot & Spot - NDF & NDF - Forward & Forward - NDF \\
\hline & \multicolumn{4}{|c|}{ Mean equation } \\
\hline \multirow[t]{2}{*}{$\alpha$} & $-8.2 E-05$ & $-1.4 \mathrm{E}-04$ & $-1.7 E-04$ & $-1.5 \mathrm{E}-04$ \\
\hline & $(-1.159)$ & $(-1.297)$ & $(-3.347)^{\star \star \star}$ & $(-1.233)$ \\
\hline \multirow[t]{2}{*}{$?$} & 0.281 & 0.122 & 0.489 & -0.008 \\
\hline & $(4.911)^{\star * *}$ & -1.354 & $(10.618)^{* * *}$ & $(-0.176)$ \\
\hline \multirow[t]{3}{*}{$\Phi$} & -0.308 & -0.144 & -0.614 & -0.063 \\
\hline & $(-4.168)^{\star * *}$ & $(-2.506)^{\star *}$ & $(-10.619)^{* * *}$ & $(-1.293)$ \\
\hline & \multicolumn{4}{|c|}{ Variance equation } \\
\hline$\omega$ & $\begin{array}{c}-0.364 \\
(-3.041)^{\star * *}\end{array}$ & $\begin{array}{c}-0.398 \\
(-3.317)^{\star * *}\end{array}$ & $\begin{array}{c}-1.362 \\
(-4.163)^{\star * *}\end{array}$ & $\begin{array}{c}-0.369 \\
(-3.388)^{* * *}\end{array}$ \\
\hline$\beta_{1}$ & 0.147 & 0.333 & 0.897 & 0.271 \\
\hline \multicolumn{5}{|l|}{$\beta_{2}$} \\
\hline$\delta$ & $\begin{array}{c}0.090 \\
(2.626)^{\star \star \star}\end{array}$ & $\begin{array}{c}0.155 \\
(3.249)^{\star * *}\end{array}$ & $\begin{array}{c}0.255 \\
(3.238)^{\star * *}\end{array}$ & $\begin{array}{c}0.151 \\
(3.411)^{\star * *}\end{array}$ \\
\hline \multirow[t]{2}{*}{$\theta_{1}$} & 0.513 & 0.983 & 0.309 & 0.983 \\
\hline & $(2.192)^{\star *}$ & $(109.295)^{\star * *}$ & $(4.266)^{\star \star \star}$ & $(123.919)^{* * *}$ \\
\hline \multirow[t]{2}{*}{$\theta_{2}$} & 0.470 & & 0.170 & \\
\hline & $(2.020)^{\star *}$ & & $(2.652)^{* * *}$ & \\
\hline \multirow[t]{2}{*}{$\theta_{3}$} & & & 0.032 & \\
\hline & & & -0.391 & \\
\hline \multirow[t]{2}{*}{$\theta_{4}$} & & & 0.417 & \\
\hline & & & $(5.669)^{\star \star \star}$ & \\
\hline \multirow[t]{2}{*}{$\gamma$} & 0.077 & -0.018 & -0.028 & -0.002 \\
\hline & $(2.378)^{\star *}$ & $(-1.467)$ & $(-0.912)$ & $(-0.239)$ \\
\hline
\end{tabular}

Note: the estimated model is:

$$
\begin{aligned}
& R_{i, t}=\alpha_{i}+\Phi_{i} \varepsilon_{i, t-1}+\partial_{i} R_{j, t-1}+\varepsilon_{i, t} \\
& \ln \left(\sigma_{i, t}^{2}\right)=\omega_{i}+\sum_{k=1}^{p} \beta_{i, k}\left|\frac{\varepsilon_{i, t-1}}{\sqrt{\sigma_{i, t-1}}}-\sqrt{2 / \pi}\right|+\sum_{k=1}^{p} \delta_{i, k} \frac{\varepsilon_{i, t-1}}{\sqrt{\sigma_{i, t-1}}}+\sum_{k=1}^{p} \theta_{i, k} \ln \left(\sigma_{i, t-1}^{2}\right)+\gamma_{i} \varepsilon_{j, t-1}^{2}
\end{aligned}
$$




\begin{tabular}{|c|c|c|c|c|}
\hline & \multicolumn{4}{|c|}{$\begin{array}{c}\text { Tabel } 12 . \\
\text { Mean and Volatility Spillover: Sub-Sample }\end{array}$} \\
\hline & \multicolumn{4}{|c|}{ Sub-sample I (Subprime crisis) } \\
\hline & NDF - Spot & Spot - NDF & NDF - Forward & Forward - NDF \\
\hline & \multicolumn{4}{|c|}{ Mean equation } \\
\hline \multirow[t]{2}{*}{$\alpha$} & 1.3E-04 & $-1.1 \mathrm{E}-04$ & $-1.7 \mathrm{E}-04$ & 1.4E-04 \\
\hline & $(17.198)^{\star \star *}$ & $(-1.006)$ & $(-3.228)^{\star * *}$ & $(0.481)$ \\
\hline \multirow[t]{2}{*}{$?$} & 0.209 & 0.018 & 0.382 & -0.004 \\
\hline & $(6.341)^{* * *}$ & $(0.146)$ & $(17.095)^{\star \star *}$ & $(-0.105)$ \\
\hline \multirow[t]{3}{*}{$\Phi$} & -0.296 & -0.183 & -0.572 & -0.045 \\
\hline & $(-5.691)^{\star \star \star}$ & $(-2.922)^{\star * \star}$ & $(-18.000)^{\star * *}$ & $(-0.749)$ \\
\hline & \multicolumn{4}{|c|}{ Variance equation } \\
\hline \multirow[t]{2}{*}{$\omega$} & -1.458 & -1.567 & -2.218 & -0.611 \\
\hline & $(-4.785)^{\star * *}$ & $(-5.570)^{\star \star *}$ & $(-7.567)^{\star * *}$ & $(-2.497)^{* *}$ \\
\hline \multirow[t]{2}{*}{$\beta_{1}$} & 0.649 & 0.562 & 1.542 & 0.118 \\
\hline & $(6.956)^{\star * *}$ & $(6.534)^{\star \star *}$ & $(8.408)^{\star * *}$ & $(0.866)$ \\
\hline \multirow[t]{2}{*}{$\beta_{2}$} & 0.529 & 0.606 & & 0.323 \\
\hline & $(6.011)^{* * *}$ & $(6.989)^{\star \star *}$ & & $(2.312)^{* *}$ \\
\hline \multirow[t]{2}{*}{$\delta$} & -0.151 & 0.056 & -0.064 & 0.266 \\
\hline & $(-2.733)^{\star \star \star}$ & $(2.006)^{\star *}$ & $(-0.693)$ & $(2.346)^{* *}$ \\
\hline \multirow[t]{2}{*}{$\theta_{1}$} & -0.240 & -0.736 & 0.022 & 0.363 \\
\hline & $(-11.307)^{* * *}$ & $(-39.769)^{* * *}$ & $(0.428)$ & $(2.585)^{* * *}$ \\
\hline \multirow[t]{2}{*}{$\theta_{2}$} & 0.294 & 0.795 & 0.477 & -0.082 \\
\hline & $(15.699)^{* * *}$ & $(57.308)^{\star \star *}$ & $(13.287)^{\star * *}$ & $(-0.479)$ \\
\hline \multirow[t]{2}{*}{$\theta_{3}$} & 0.893 & 0.870 & 0.384 & 0.688 \\
\hline & $(74.465)^{\star * *}$ & $(44.985)^{* * *}$ & $(8.372)^{\star * *}$ & $(4.892)^{* * *}$ \\
\hline \multicolumn{5}{|l|}{$\theta_{4}$} \\
\hline \multirow[t]{2}{*}{$\gamma$} & 0.076 & 0.023 & -0.079 & -0.002 \\
\hline & $(2.722)^{\star * *}$ & $(2.432)^{* *}$ & $(-2.165)^{\star *}$ & $(-0.092)$ \\
\hline
\end{tabular}

Note: the estimated model is:

$$
\begin{aligned}
& R_{i, t}=\alpha_{i}+\Phi_{i} \varepsilon_{i, t-1}+\partial_{i} R_{j, t-1}+\varepsilon_{i, t} \\
& \ln \left(\sigma_{i, t}^{2}\right)=\omega_{i}+\sum_{k=1}^{p} \beta_{i, k}\left|\frac{\varepsilon_{i, t-1}}{\sqrt{\sigma_{i, t-1}}}-\sqrt{2 / \pi}\right|+\sum_{k=1}^{p} \delta_{i, k} \frac{\varepsilon_{i, t-1}}{\sqrt{\sigma_{i, t-1}}}+\sum_{k=1}^{p} \theta_{i, k} \ln \left(\sigma_{i, t-1}^{2}\right)+\gamma_{i} \varepsilon_{j, t-1}^{2}
\end{aligned}
$$




\begin{tabular}{|c|c|c|c|c|}
\hline \multicolumn{5}{|c|}{$\begin{array}{l}\text { Tabel } 13 . \\
\text { Mean and Volatility Spillover: Sub-Sample }\end{array}$} \\
\hline & \multicolumn{4}{|c|}{ Sub-sample II (Europe sovereign crisis) } \\
\hline & NDF - Spot & Spot - NDF & NDF - Forward & Forward - NDF \\
\hline & \multicolumn{4}{|c|}{ Mean equation } \\
\hline$\alpha$ & $\begin{array}{l}-1.2 \mathrm{E}-04 \\
(-1.048)\end{array}$ & $\begin{array}{l}-3.2 E-05 \\
(-0.254)\end{array}$ & $\begin{array}{c}-1.2 E-04 \\
(-1.057)\end{array}$ & $\begin{array}{l}-5.1 E-05 \\
(-0.390)\end{array}$ \\
\hline$?$ & $\begin{array}{c}-0.030 \\
(-0.304)\end{array}$ & $\begin{array}{c}0.227 \\
(1.567)\end{array}$ & $\begin{array}{c}0.237 \\
(2.912)^{\star * *}\end{array}$ & $\begin{array}{c}0.109 \\
(2.240)^{* *}\end{array}$ \\
\hline \multirow[t]{2}{*}{$\Phi$} & $\begin{array}{c}0.055 \\
(-0.383)\end{array}$ & $\begin{array}{c}-0.164 \\
(-1.821)^{*}\end{array}$ & $\begin{array}{c}-0.379 \\
(-3.878)^{\star * *}\end{array}$ & $\begin{array}{c}-0.129 \\
(-1.879)^{*}\end{array}$ \\
\hline & \multicolumn{4}{|c|}{ Variance equation } \\
\hline$\omega$ & $\begin{array}{c}-0.983 \\
(-2.834)^{* * *}\end{array}$ & $\begin{array}{c}-0.983 \\
(-3.568)^{\star * *}\end{array}$ & $\begin{array}{c}-1.551 \\
(-4.129)^{\star * *}\end{array}$ & $\begin{array}{c}-0.985 \\
(-2.932)^{* * *}\end{array}$ \\
\hline$\beta_{1}$ & $\begin{array}{l}0.155 \\
-1.457\end{array}$ & $\begin{array}{c}0.212 \\
(2.197)^{\star *}\end{array}$ & $\begin{array}{c}0.130 \\
(1.095)\end{array}$ & $\begin{array}{c}0.278 \\
(3.323)^{\star \star *}\end{array}$ \\
\hline$\beta_{2}$ & & & $\begin{array}{l}-0.168 \\
(-1.466)\end{array}$ & \\
\hline$\delta$ & $\begin{array}{c}0.151 \\
(2.668)^{* * *}\end{array}$ & $\begin{array}{c}0.251 \\
(2.829)^{* * *}\end{array}$ & $\begin{array}{c}0.258 \\
(4.883)^{\star * *}\end{array}$ & $\begin{array}{c}0.250 \\
(2.770)^{\star * *}\end{array}$ \\
\hline$\theta_{1}$ & $\begin{array}{c}0.613 \\
(2.895)^{\star * *}\end{array}$ & $\begin{array}{c}0.929 \\
(41.555)^{\star * *}\end{array}$ & $\begin{array}{c}0.728 \\
(3.167)^{\star \star *}\end{array}$ & $\begin{array}{c}0.930 \\
(33.897)^{\star * *}\end{array}$ \\
\hline$\theta_{2}$ & $\begin{array}{c}0.324 \\
(1.545)\end{array}$ & & $\begin{array}{c}0.006 \\
(0.025)\end{array}$ & \\
\hline$\theta_{3}$ & & & $\begin{array}{c}0.137 \\
(1.054)\end{array}$ & \\
\hline$\theta_{4}$ & & & & \\
\hline$\gamma$ & $\begin{array}{c}0.113 \\
(2.626)^{\star * *}\end{array}$ & $\begin{array}{c}0.026 \\
(1.689)^{*}\end{array}$ & $\begin{array}{c}0.098 \\
(2.690)^{\star * *}\end{array}$ & $\begin{array}{c}-0.007 \\
(-0.553)\end{array}$ \\
\hline
\end{tabular}

Note: the estimated model is:

$$
\begin{aligned}
& R_{i, t}=\alpha_{i}+\Phi_{i} \varepsilon_{i, t-1}+\partial_{i} R_{j, t-1}+\varepsilon_{i, t} \\
& \ln \left(\sigma_{i, t}^{2}\right)=\omega_{i}+\sum_{k=1}^{p} \beta_{i, k}\left|\frac{\varepsilon_{i, t-1}}{\sqrt{\sigma_{i, t-1}}}-\sqrt{2 / \pi}\right|+\sum_{k=1}^{p} \delta_{i, k} \frac{\varepsilon_{i, t-1}}{\sqrt{\sigma_{i, t-1}}}+\sum_{k=1}^{p} \theta_{i, k} \ln \left(\sigma_{i, t-1}^{2}\right)+\gamma_{i} \varepsilon_{j, t-1}^{2}
\end{aligned}
$$

Following Ma et al (2004) and Misra and Behera (2006), it may also be interesting to evaluate the relationship between onshore and offshore market from the yield spread between domestic and offshore. We calculate the NDF implied yield rate base on equation (2) as previously mentioned. We also take the 10Y Indonesian Government Bond as a proxy of domestic market. This is because the bond is the most liquid instrument in the market at the moment and most of the investors consider the yield of bond as a benchmark. In addition, the yield itself may also represent the pressure to the exchange rate. If the yield falls compare to the offshore interest rate then it may give depreciation pressure to the IDR and vice a versa. It can also be 


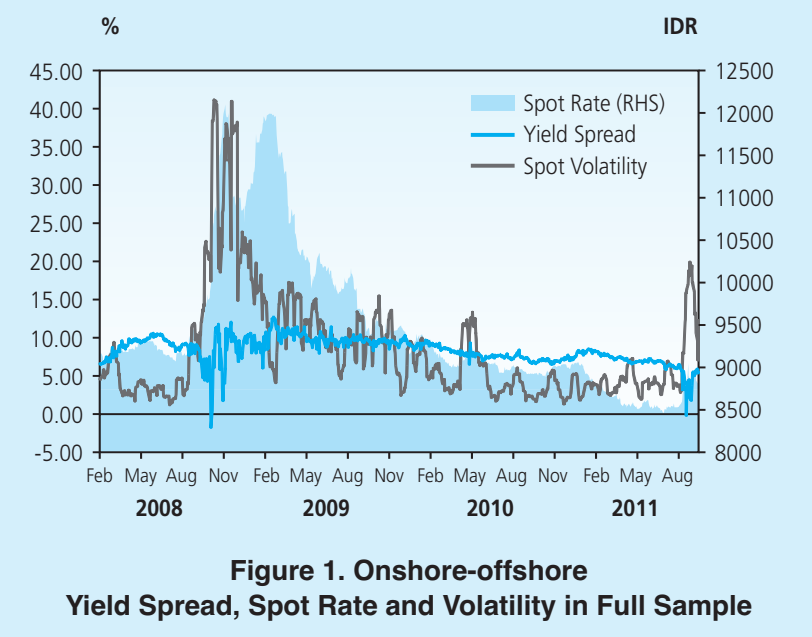

argued that the bigger spread between the domestic interest rate and NDF implied rate, more pressure for the currency to appreciate. The smaller spread between these variables may reflect the tendency for the currency to depreciate since the investors may seek other countries that give more gain for them. Therefore, we plot these variables with spot rate and spot volatility to see whether it may contain the information.

From full sample, we find that positive value of the spread between domestic interest rate and NDF rate tends to be followed by appreciation (Figure1). We also observe that the volatility tends to be higher when the spread is small or negative.However, there is only small indication that higher spread may push the appreciation pressure.

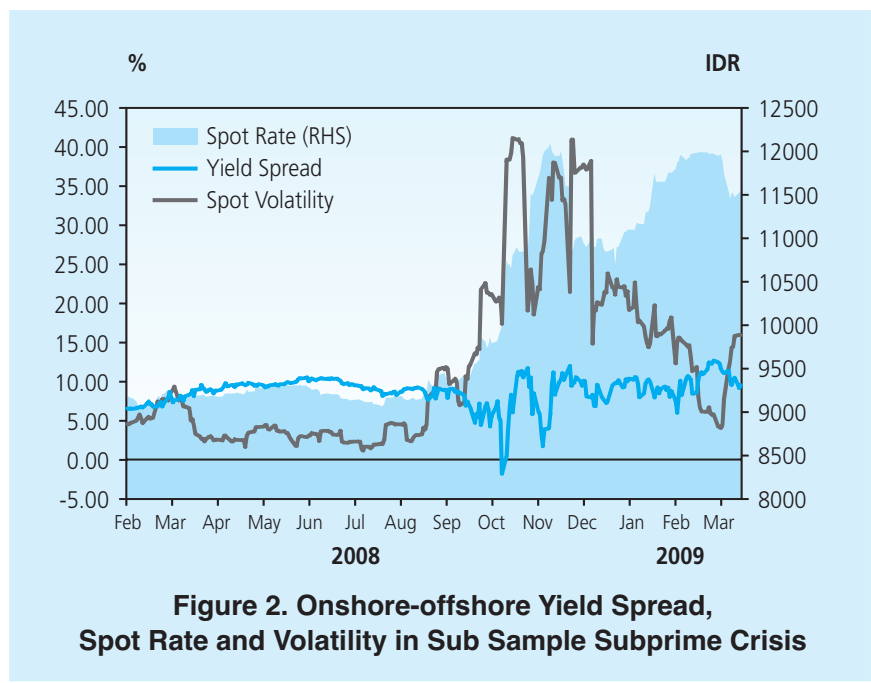




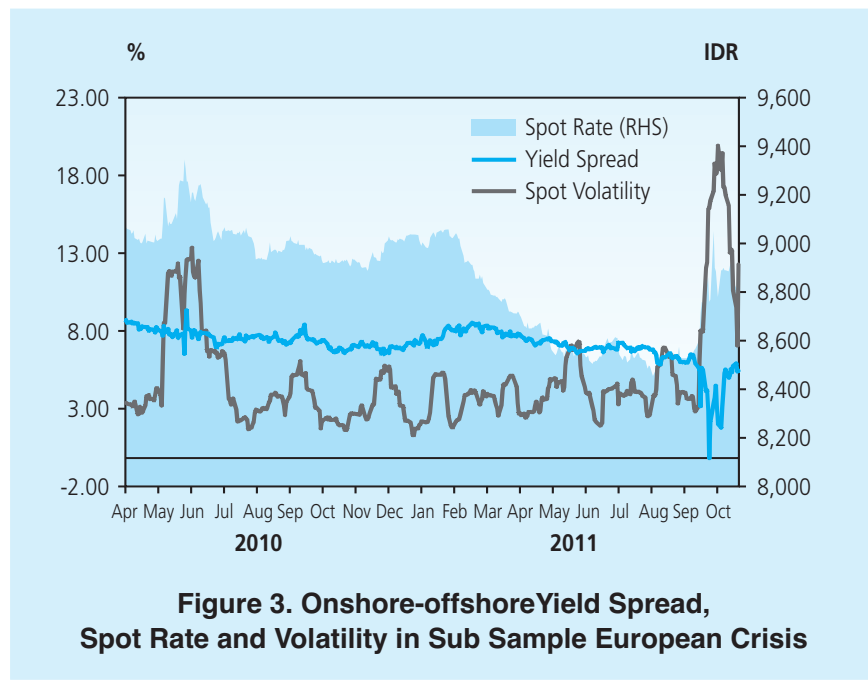

In both sub sample subprime crisis and European crisis, we also got the similar finding with full sample. We find that positive value of the spread between domestic interest rate and NDF rate tends to be followed by appreciation, vice versa (Figure 2 and Figure 3). We also observe that the volatility tends to be higher when the spread is small or negative.However, there is only small indication that higher spread may push the appreciation pressure.

\section{CONCLUSION}

This paper aims to examine the information spillover between offshore and onshore IDR market. The analysis covers daily data for the period of 2008 - 2011, as well as splitting our sample to investigate the first-moment and second-moment transmission mechanism in the event of global crises after Subprime crisis and following the surge of Europe sovereign crisis. Using EGARCH model, this paper find the following conclusions.

First, the persistent volatility in all IDR/USD currency markets is evident. Second, the leverage effects are present in the rupiah exchange rates, indicating that IDR/USD markets have responded more to depreciation than appreciation, which is generally common in emerging market currencies. One possible lesson can be noted is that there would be more efforts needed for policy maker to stabilize the IDR exchange rate in the time of depreciation pressures than appreciation. Third, the evidence of mean spillover are observed to be uni-directional; from NDF to both spot and forward rupiah markets. However, there are two ways return transmission between NDF and forward rate changes in the period of Europe crisis. Fourth, on the volatility, the spillover is only significant from NDF market to spot market for the entire period. However, in the time of crises, there is interdependence between volatility in offshore NDF and onshore spot rate changes, while information transmission is only valid from NDF to 
forward rate changes, not the other way around. The different behavior between the return and the volatility spillovers in Rupiah marketis important both for investors as well as for the authorities. Fifth, the negative spread of domestic interest rate may lead to depreciation pressure on the currency and positive spread may indicate the appreciation pressure.

This paper open for future studies especially in the area of micro-structure of foreign exchange market including the Rupiah NDF response to the monetary policy and the behavior of NDF intra-day movement. 


\section{REFERENCES}

Bekaert, G. dan G. Wu, 2000, "Asymmetric volatility dan risk in equity markets", The Review of Financial Studies, 13(1), pp 1-42.

Cairns, J., C. Ho dan R. N. McCauley, 2007, "Exchange rates dan global volatility: implications for Asia-Pacific currencies", BIS Quarterly Review, March 2007.

Colavecchio, R. dan M. Funke, 2006," Volatility transmission between Renminbi dan AsiaPacific on-shore dan off-shore US dollar futures", BOFIT Discussion Paper, 16.

Christiansen, C., 2003, "Volatility spillover effects in European bond markets", Working Paper, Aarhus School of Business.

Eagle, R. F. dan V. K. Ng., 1993, "Measuring dan testing the impact of news on volatility", Journal of Finance, 48(5), 1749-1778.

Izawa, H, 2006, "An empirical test of the efficiency hypothesis on the Renminbi NDF in Hongkong market", Discussion Paper Series no. 196, Research Institute for Economic dan Business Administration, Kobe University.

Lipscomb, L., 2005, "An overview of non-deliverable foreign exchange forward markets", Federal Reserve New York Paper.

Lee, C. L., 2010, "An examination of volatility dynamic in Australian REIT futures", The $16^{\text {th }}$ Pacific Rim Real Estate Society Conference, Wellington, New Zealand.

Ma, G., C. Ho dan R. N. McCauley, 2004, "The markets for non-deliverable forwards in Asian currencies", BIS Quarterly Review, June 2004.

Mehra, S. dan H. Behera, 2006, "Non-deliverable foreign exchange forward market: An overview", Reserve Bank of India Occasional Paper, 27(3)

Michayluk, D., P. J. Wilson dan R. Zurbruegg, 2006, "Asymmetric volatility, correlation dan return dynamic between US dan UK real estate markets", Real Estate Economics, 34(1), pp 109-131.

Morales, L. dan M. O’Donnell, 2006, "Volatility spillover between stock prices dan exchange rates: empirical evidence from six APEC economies", All China Economic Conference , Hong Kong , $18^{\text {th }}-20$ th December .

Ng, A., 2000, "Volatility spillover effects from Japan dan US to the Pacific-Basin", Journal of International Money dan Finance, 19, pp 207-233.

Park, J., 2001, "Information flows between non-deliverable forwards (NDF) dan spot markets: Evidence from Korean currency", Pacific Basin Finance Journal, 9(4), pp 363-377, 
Shittu O.I. dan M.J. Asemota, 2009, "Comparison of Criteria for Estimating the Order of Autoregressive Process: A Monte Carlo Approach", European Journal of Scientific Research,vol.30, pp.409-416

Stevenson, S., 2002, "An examination of volatility spillover in REIT returns", Journal of Real Estate Portfolio Management, 8(3), pp 229-238.

Wu, R. S., 2005, "International transmission effect of volatility between the financial markets during the Asian financial crisis", Transition Studies Review, 12(1), pp 19-35. 
This page is intentionally left blank 